Please do not remove this page

RMIT

UNIVERSITY

\title{
Beyond skills: embodying writerly practices through the doctorate
}

Barnacle, Robyn; Dall'Alba, Gloria

https://researchrepository.rmit.edu.au/esploro/outputs/9921858787201341/filesAndLinks?institution=61RMIT_INST\&index=null

Barnacle, R., \& Dall'Alba, G. (2014). Beyond skills: embodying writerly practices through the doctorate. Studies in Higher Education, 39(7), 1139-1149. https://doi.org/10.1080/03075079.2013.777405

Document Version: Accepted Manuscript

Published Version: https://doi.org/10.1080/03075079.2013.777405

Repository homepage: https://researchrepository.rmit.edu.au

(C) 2013 Society for Research into Higher Education

Downloaded On 2023/04/27 01:08:56 +1000

Please do not remove this page 
Thank you for downloading this document from the RMIT Research Repository.

The RMIT Research Repository is an open access database showcasing the research outputs of RMIT University researchers.

RMIT Research Repository: http://researchbank.rmit.edu.au/

\section{Citation:}

Barnacle, R and Dall'Alba, G 2013, 'Beyond skills: embodying writerly practices through the doctorate', Studies in Higher Education, vol. Online, pp. 1-11.

See this record in the RMIT Research Repository at:

http://researchbank.rmit.edu.au/view/rmit:20810

Version: Accepted Manuscript

Copyright Statement: @ 2013 Society for Research into Higher Education

Link to Published Version:

http://dx.doi.org/10.1080/03075079.2013.777405 
Beyond skills: embodying writerly practices through the doctorate

\section{Robyn Barnacle* and Gloria Dall'Alba}

School of Graduate Research, RMIT University, Melbourne, Australia; School of

Education, University of Queensland, Brisbane, Australia.

*robyn.barnacle@rmit.edu.au

Please note; this article was accepted for publication by Studies in Higher Education in February 2013. Where possible, please refer to the published article.

Summary: This article explores the features and potential of an embodied, rather than merely skills based, approach to doctoral writing. Our conceptual framework is derived from the phenomenological literature, particularly Heidegger's critique of modern life as permeated by a quest for mastery and control. We address two key questions with respect to this: Firstly, what role might the quest for mastery as achieving command or control play in impeding writing and undermining an embodied writerly practice? Secondly, to what extent might narrow skills based approaches to writing unwittingly promote the quest for mastery and therefore encourage, rather than diminish, the anxieties that doctoral research writers may feel? 


\section{Beyond skills: embodying writerly practices through the doctorate}

This article explores the features and potential of an embodied, rather than merely skills based, approach to doctoral writing. Our conceptual framework is derived from the phenomenological literature, particularly Heidegger's critique of modern life as permeated by a quest for mastery and control. We address two key questions with respect to this: Firstly, what role might the quest for mastery as achieving command or control play in impeding writing and undermining an embodied writerly practice? Secondly, to what extent might narrow skills based approaches to writing unwittingly promote the quest for mastery and therefore encourage, rather than diminish, the anxieties that doctoral research writers may feel?

Keywords: doctoral writing; writing skills; mastery; embodiment; authoritative writing.

\section{Introduction}

Writing a doctoral thesis is well known for inducing anxiety. Given the scale of the task and the nature of writing itself, this is understandable and, perhaps to some extent at least, inevitable. There is evidence that many universities are addressing these issues through increasing writing support programs, in the form of workshops, writing groups, and other measures. Doctoral candidates are also under increasing pressure to publish during the doctorate, for a number of reasons, but most notably career development and in the interests of institutional research performance (Kamler and Thomson 2006; Aitchison, Kamler and Lee 2010). In this paper we are interested in these developments from the perspective of what it means to become research writers in an age characterised by Martin Heidegger as governed by a quest for mastery as control. Heidegger laments that we moderns no longer know how to think because thinking has become usurped by this quest, ironically reorienting us away from that which calls us to think in the first place. To put it another way, just as writing success becomes 
increasingly important for doctoral candidates and graduates, writing itself is arguably becoming increasingly detached from what it is supposed to be about, thus undermining efforts to ameliorate writing anxieties and promote good writing and productivity. This raises a number of questions, such as, do efforts aimed at improving writing skills run the risk of unwittingly promoting the quest for mastery as control and therefore encouraging, rather than diminishing, the anxieties they are intended to address?

In this paper we explore such questions through an embodied approach to doctoral writing. This approach seeks to go beyond an approach focusing on skills development alone. By exploring what it might mean to embody writerly practices, we seek to engage productively with both the joy and risk at the heart of writing - the instability and uncertainty of meaning. In practice, this might mean, for example, writing in such a way as to encourage readers to play with meanings, imagine alternatives and, more broadly, engage in the co-production of meaning.

\section{Becoming research-writers}

As an institution, the author is dead: his civil status, his biographical person have disappeared; dispossessed they no longer exercise over his work the formidable paternity whose account literary history, teaching, and public opinion had the responsibility of establishing and renewing... (Barthes 1976, 27)

The notion of the death of the author may seem an odd place to start a paper on doctoral writing - a genre in which, surely, authorial presence is valued more highly than perhaps in any other. What is the doctoral thesis if not the site in which an author establishes credibility as just that: an authoritative author? It is not uncommon in most 
universities that there is even a requirement to sign a statement that the work is entirely one's own. Clearly this raises the question: if the author is dead, then whose thesis is it? In the interests of avoiding scandal, let's just say from the outset that the thesis belongs to the research candidate who wrote it. Roland Barthes' declaration refers to the end of a certain kind of author understood as an originator of meaning, transferring meaning to an otherwise passive reader as consumer. In the words of Barthes:

On the stage of the text, no footlights: there is not, behind the text, someone active (the writer) and out front someone passive (the reader); there is not a subject and an object. (Barthes 1976, 16)

The author, conceived in this way, writes what Barthes refers to as a 'readerly text', intended, perhaps confusingly, to be consumed, rather than read in an active sense. Barthes used the notion of a 'writerly text' to characterise an alternative kind of writing that seeks not only to include the reader in the production of meaning but also actively promote textual plasticity and the co-production of meaning (see Barthes 1970).

These ideas may seem out of place in a discussion of doctoral writing, particularly given that the main focus of Barthes' considerations was literary criticism. Our interest in these ideas is not so much to argue that doctoral theses need to be more experimental or even literary. We are interested in how such a conception of writing might be used productively to highlight the precariousness of meaning and thereby unsettle the authorial status of the doctoral writer. The genre of doctoral writing is particularly loaded, entailing a set of responsibilities and opportunities. Not least of these is that the thesis is written for the purposes of assessment and the writer is 
required to demonstrate research capability to the examiner, through the text. Legibility is particularly important in this context, given the obligation of the author to make the research available, not only to the examiners but the broader discipline as well. In this context, Barthes' ideas about treating the reader as a producer, rather than consumer, of meaning are particularly potent and challenging. Risk minimisation is an understandable inclination in this context; both doctoral candidates and their advisors will often seek to pin down meaning as much as possible to avoid confusion or misunderstanding. An alternative is to try and recruit the examiner and other readers into a process of meaning co-production. This would mean encouraging an active reading through a more porous and open text, without sacrificing clarity. Doing this, however, requires re-thinking what it means to be an authoritative writer.

How the doctoral thesis, indeed any text, will be interpreted is not entirely within the author's control. And yet, as we have discussed, the thesis is the text against which the doctoral candidate's performance as researcher will be assessed. Note here that we have moved to position the thesis as the site of a performance, a research performance, or enactment. But it is not an enactment in which the candidate is alone. As Max van Manen describes it, a writerly text is one "that makes of the reader a writer - rewriting the text again at every reading' (2002a, 238). From the point of view of a writer, the question becomes how to assemble the text in such a way as to promote such writerly production in a fortuitous way. This does not mean to enforce the will of the author by stealth but instead to write for active engagement by the reader, rather than passive reception. As Barthes goes on to say in the above quote, the author may be dead: '...but in the text, in a way, I desire, the author: I need his figure (which is neither his representation nor his projection), as he needs mine...' $(1976,27)$. One way that 
writers promote writerly texts is to anticipate objections, questions, and possible interpretations or misinterpretations, actively responding to these in the text and encouraging readers to consider alternative points of view. For the purposes of this paper, we are interested in how such a compositional practice and approach to reading and writing might inform approaches to doctoral theses writing.

What does it mean to become adept research-writers, or to master such writing? Often mastery is understood in terms of achieving command or, in other words, learning to perform or grasp something in such a way that there is no longer uncertainty about how it is done or what it involves. There is also, however, another sense of mastery in which mastery is itself transcended - a kind of 'mastery of mastery'. This becomes evident in the following passage from Leon van Schaik reflecting on mastery in the context of professional practice, in this case architecture: 'Mastering a field of endeavour prepares you to become a practitioner in a field. What kind of mastery prepares you to go beyond this and become a creative innovator in that field?' (van Schaik 2005, 8). In the way that it is conceptualised here, having mastery can manifest as competence and 'knowing ones' field' but it can also mean going beyond such competence in contributing to actively transforming that field. It is clear that the compositional practices implied by the notion of a writerly text challenge a conventional notion of mastery as merely achieving command or control. In a writerly text, meaning by definition exceeds the intent of the author. This is the case not just in the reading, but also in the writing itself.

This is an idea reminiscent of something that Winnie the Pooh touches on in the following passage from The House at Pooh Corner: 
'And that's the whole poem,' he said. 'Do you like it, Piglet?'

'All except the shillings,' said Piglet. 'I don't think they ought to be there.'

'They wanted to come in after the pounds,' explained Pooh, 'so I let them. It is the best way to write poetry, letting things come.' (Milne 2007/1928, 31, our italics).

In this passage, Pooh is seeking to be receptive to the agency of the poem itself or, in other words, to the writing process. Expressed in a different form: 'the writer dwells in the space that the words open up' (van Manen 2002b, 2). This points to an aspect of writing 'mastery' as letting go, and having the confidence to 'let things come.' It also indicates the way in which the text exceeds the author even during the writing process: the author is positioned both within and outside the text in a kind of iterative coproduction. Heidegger alludes to this phenomenon when he says: 'One of the exciting experiences of thinking is that at times it does not fully comprehend the new insights it has just gained' $(1971,72)$.

While the unexpected insights that come through thinking or writing can be exciting, they can also be unsettling and disorienting, as van Manen explains:

... in the experience of writing (or trying to write) something happens to me. I seem to be seeking a certain space. A "writerly" space. In this space I am no longer quite myself. Just as in reading a compelling story the self of the reader has slipped away, so in the act of writing the "self" has become partially erased. It is like falling into a twilight zone, where things are no longer recognizably the same, where words are displaced, where I can lose my orientation, where anything can happen. (2002b, 1-2) 
The precariousness of such writing has implications for becoming research-writers and how mastery is understood. As Heidegger says of the poet: 'mastery consists precisely in this, that the poem can deny the poet's person and name' $(2001 / 1951,193)$. Clearly the notion of mastery as command or control is anathema to a writing practice that seeks to actively engage precariousness and openness to other possible meanings, but this does not have to imply the opposite, or randomness. Below we examine the notion of mastery in more detail before exploring the precariousness that enables discovery through writing.

\section{Mastery in the age of Gestell}

In some of his later works, Heidegger highlights the way in which our age is governed by a quest for mastery and control. One of the ways in which this quest can be clearly seen is in our current pre-occupation with a particular form of accountability, such as recording the achievement of milestones by research candidates during the research process; assembling the publications and presentations from this research; and counting the number of research 'completions' within a designated time frame. While some of these practices may be useful, including to research candidates themselves, the heightened emphasis they are afforded during the complex process of learning to be a researcher risks undervaluing the contribution and quality of the research itself. These procedures are also unlikely to contribute to the promotion of thoughtful, critical reflection about the research topic or engender a sense of wonder that engaging in research can cultivate. In addition, while attention is directed to readily measurable 'outcomes,' it is potentially diverted from providing the support needed by research candidates and their advisors along the way. 
The emphasis on this form of accountability demonstrates an instrumental framing of processes and activities that was of concern to Heidegger. He expressed disquiet about the way in which our increasingly technologised world frames both human being and nature as resources to be used or exploited. In an introduction to Heidegger's essay, The question concerning technology, William Lovitt described the efforts towards mastery and control that had troubled Heidegger, as follows:

... contemporary man's inveterate drive to master whatever confronts him is plain for all to see. Technology treats everything with 'objectivity.' The modern technologist is regularly expected, and expects himself, to be able to impose order on all data, to 'process' every sort of entity, nonhuman and human alike, and to devise solutions for every kind of problem. He is forever getting things under control. (1977, xxvii)

Indeed, research itself is readily conceived as filling a 'gap' in the literature (Sandberg and Alvesson 2011) in a manner that reflects a desire to 'map' a field of endeavour and thereby gain control over it.

Using a term from early Greek philosophy, Heidegger described the technologisation of human being and nature as Gestell or 'enframing': 'Enframing means that way of revealing which holds sway in the essence of modern technology and which is itself nothing technological' (Heidegger 1977/1954, 20). For Heidegger, this 'way of revealing,' or of conceiving human being and nature, reduces us to less than we are, or can be. It transforms nature and ourselves into useful or exploitable commodities: 
Everywhere everything is ordered to stand by, to be immediately at hand, indeed to stand there just so that it may be on call for a further ordering. Whatever is ordered about in this way has its own standing. We call it the standing-reserve. (Heidegger 1977/1954, 17)

In describing the instrumental, technological hold over our age as a 'way of revealing,' Heidegger called into question 'the talk we hear more frequently, to the effect that technology is the fate of our age, where "fate" means the inevitableness of an unalterable course' (p. 25). He challenged the notion that we are confined to what he described as 'a stultified compulsion to push on blindly with technology or, what comes to the same thing, to rebel helplessly against it and curse it' (pp. 25-26). Of particular concern for Heidegger:

[When man] is nothing but the orderer of the standing-reserve, then he comes to the very brink of a precipitous fall; that is, he comes to the point where he himself will have to be taken as standing-reserve. Meanwhile man, precisely as the one so threatened, exalts himself to the posture of lord of the earth. In this way the impression comes to prevail that everything man encounters exists only insofar as it is his construct. $(1977 / 1954,27)$

An expectation of achieving mastery as control follows from the notion that we are lords over the earth. As with previous historical events, the recent spate of natural disasters around the globe and the collapse of financial markets have failed to disabuse us of this misconception, which lives on largely unchallenged, as before. These events demonstrate that while we may seek to gain complete mastery and control over the world, our efforts are often thwarted by unpredictable repercussions. Parallels can also 
be found in the unstable and uncertain process of assembling a text that relies upon engagement by readers, where the outcome is far from assured. As van Manen observes, 'There is no magic beginning, no sure method, no guarantee that entering a fresh page will take us to the other side' (van Manen and Adams 2009, 13). Writing support programs for doctoral candidates that promise such mastery and control over the writing process through skills acquisition cannot, therefore, live up to this promise. As a consequence, they are likely to unwittingly exacerbate the anxieties they are intended to address.

Implicitly dismissing a quest for mastery and control, Maurice Merleau-Ponty regards meaning as necessarily unstable and uncertain. He pointed out that 'ambiguity is of the essence of human existence, and everything we live or think has always several meanings' $(1962 / 1945,169)$. It is precisely this inherent ambiguity that provides the openings and challenges in composing writerly texts and which cannot be brought entirely under control. van Manen highlights a form of ambiguity in the writing process when he points out that 'writing can mean both insight or illusion. And these are values that cannot be decided, fixed or settled, since the one always implies, hints at, or complicates the other' (2002a, 237). Through promoting recognition among doctoral candidates that writing necessarily involves ambiguity, research advisors and writing support programs can contribute to reducing the anxiety that a quest for mastery invokes. Working with, and tolerating, ambiguity can instead offer a constructive way forward in the writing process. It is in recognition of this ambiguity that writers anticipate and respond to possible objections, questions, interpretations or misinterpretations as they write a text. Here, advisors have a key role to play in 'talking back' to the texts that research candidates compose, through questions, compliments, 
objections and so on. In doing so, advisors demonstrate how reading always transcends the writer's intent, as well as modelling how to anticipate a range of responses from potential readers. They also illustrate a distinction between a closed, 'mastered' text and an open, invitational text. Opening up the text in this way and anticipating responses can serve to address examiners' concerns in advance, as it were. Perhaps somewhat paradoxically, such open, porous texts can therefore be more acceptable to varied examiners than controlled texts.

Not only is ambiguity inherent in meaning making, including in the writing process, but Merleau-Ponty identified ambiguity as relevant to the very way in which we experience our body: 'I apprehend my body as a subject-object, as capable of “seeing" and "suffering"' (1962/1945, 95). This bodily ambiguity - or ambiguity of embodiment - is evident in the performance of writing a text. What might be called the attempt to enact meaning through text. For instance, it can be seen in the manner in which we use our body to manipulate writing tools in transforming thoughts and ideas into written text, as well as in the anxiety or exhilaration we can feel about the text we have produced. Moreover, as Merleau-Ponty points out, it is our bodily engagement with things and people in our world that enables us to have a world at all (p. 82). The ambiguity that characterises embodiment further calls into question, then, a notion that research writing can be reduced to skills acquisition. Instead, it highlights the investment of the self, including the commitment and unsettling risk that research writing necessarily involves. This investment of the self means it is necessary for research advisors to address not only the process of formulating and clarifying ideas through writing, but also the undulating commitment, engagement and sense of risk experienced by research candidates. 


\section{Integrating knowing, acting and being researcher-writers}

The investment of the self in the process of learning, including in learning to write and to research, is a theme we have explored in previous work. For a number of years now we have been working to re-conceptualise how learning and knowledge are understood in higher education discourse and practice. We do this through what we have called an ontological approach to knowing and learning (Barnacle and Dall'Alba, 2011; Dall'Alba and Barnacle 2007; Dall'Alba 2005, 2009, and; Barnacle 2005). One of our key moves in this work is to argue for a shift in the focus of higher education programs from knowledge-in-itself to learning as embodied and enacted. Accordingly, we refer to knowing, as a verb, rather than knowledge, as a noun, to make the point that it needs to be understood as enacted, rather than possessed. This conceptualisation has some similarities to Donald Schön's concept of 'knowing-in-action,' in which he underscores that 'the knowing is in the action' $(1987,25)$. However, Schön's concept has an epistemological emphasis (on knowing and doing) in contrast to our ontological approach to knowing and learning. We argue that the aim of all higher education programs, higher degrees by research included, is to promote the integration of knowing, acting and being.

In a conventional account, knowledge and knowing are restricted to an ideal realm of thoughts, ideas and concepts, even where these are subsequently to be applied in practical contexts. However, knowing can also be situated within the materiality, and spatial and temporal specificity, of embodiment. In this account, knowing is not treated as reducible to thought or the discursive, as is often the case. Embodiment refers to inhabiting the body within an historical, material, cultural and social place, although it 
isn't entirely determined by this situatedness (see Merleau-Ponty 1962/1945). Knowing thus transforms from the merely intellectual, or something that can be accumulated within a (disembodied) mind, to something inhabited and enacted: a way of thinking, making and acting. Indeed, a way of being. This way of reconceptualising knowing has the potential to transform the way that learning to research, and becoming research writers, is conceived. Becoming knowledgeable remains important but notions such as knowledge transfer or acquisition become of less use as they imply that "content" can be uploaded and downloaded, computer style; traded and exchanged; accepted or declined. This is the model of knowledge as commodity, such that, as Robyn Barnacle has argued:

\footnotetext{
Having and doing are distinct. Integration does come, but not until an appropriate practice context is identified. There is a temporal disjuncture, therefore, between learning and doing (not to mention being), such that knowledge gets treated as an instrument of convenience. $(2005,186)$
}

Embodiment is a useful notion for reconceptualising what it means to become research writers because it turns attention to aspects of being that can be overlooked when becoming a researcher is understood without reference to the identity and ontological aspects involved. These aspects include, for example, commitment, resistance, gender and desire. As Nigel Blake and colleagues note in regards to the skills debate in higher education, a common propensity to reduce a range of human abilities and qualities to 'skills' or 'competencies' overlooks the engagement, commitment and risk involved: "what are commonly called skills are not activities to which we give anything of ourselves' $(2000,26)$. Indeed, without commitment, or caring about the outcome, the development of important skills and knowledges, like those involved in 
learning to research, is unlikely to occur at all, or will do so only in a superficial way. As Barnacle has argued, an instrumental account of knowledge:

...situates the knower at arm's length from what is known. Consequently, knowledge on this model does not produce hardship, struggle or grief. And nor is it confrontational or difficult. Rather, knowledge is conceived as fundamentally plentiful, useful and productive. The knowledge worker is untroubled and the potential of their knowledge unlimited. $(2005,185)$

When knowledge is understood as created, embodied, and enacted, a shift occurs such that learning and becoming (a researcher) requires integrating ways of knowing, acting, and being within a broad range of related practices. This approach seeks to actively engage the very real challenges of ensuring 'having and doing' are indistinct. In our experience, one of the key places that these tensions play out is with regards to the requirements of scholarly or research writing.

Writing involves anxiety, as a researcher is brought into being through the process. Moreover, it is a site in which meaning is itself performed and brought into being: writing is meaning making. As van Manen points out, language can both afford and obscure this process of making meaning:

Strangely, in the space of the text our experience of language seems to vacillate between transparency and impenetrability. One moment I am totally and self-forgetfully entering this text - which opens up its own world. The next moment the entrance is blocked; or perhaps, I am re-entering the text with an acute awareness of its linguistic obscurity and darkness. $(2002 b, 3)$ 
Writing can be fraught, then, because it is not simply a matter of decanting the contents of one's head - 'the what I want to say' - as if from a full vessel onto an empty page. This treats writing as mere reportage; a notion encapsulated by the ubiquitous use of the expression 'write up' in the context of thesis writing. As others, such as Barbara Kamler and Pat Thomson (2006), also lament, such notions overlook the potential for discovery through writing. Meaning is made through the writing and reading process, so it emerges through writing and reading. It can be useful, therefore, to recognise the "double struggle" involved in thesis writing as an exercise in both meaning making, or discovery, and learning how to do research writing, or be a research writer - bearing in mind that in practice, of course, the two are necessarily intertwined. Moreover, as our discussion of Barthes highlights, in neither making meaning nor learning research writing is the interrelation with the 'other' - for example, readers in the first case and thesis examiners in the second-incidental.

The simultaneity of meaning making and learning to be a research writer becomes more apparent when writing is seen as a social practice, rather than just a technical skill. As Kamler and Thomson argue, this involves “...meaning making and learning to produce knowledge in particular disciplines and discourse communities" $(2006,4)$. Doctoral research writers can be seen as becoming acculturated into the writing practices of their broader disciplinary or practice community. As research advisors and examiners - embody these disciplinary writing practices, they can provide a bridge to those practices and communities. Writing any academic text successfully, therefore, has several dimensions, including what Kamler and Thomson describe as the 'text work' involved in performing the conventions, genres and textual practices of one's 
discipline; 'meaning making' that contributes to advancing the discipline; and 'identity work' involved in positioning oneself authoritatively with respect to that discipline and becoming a writer. These dimensions are embodied, rather than merely technical, in the sense that they are enacted in, and through, the writing. They are also reminiscent of Blake et al (2000) in requiring us to 'give something of ourselves.' Moreover, these dimensions of writing academic texts also require us to change and become something or, rather, someone - else. For example, they entail taking on the identity of scholar within the discipline in question and being authoritative. The notion of 'generic skills' fails to do justice to the ontological necessity of actually becoming a writer in this sense.

\section{The precariousness of writing}

As we have touched on above, the notion of authority, and what it means to write scholarly texts authoritatively, needs to be approached with caution. While we would not want to dispense with notions of authority and mastery entirely, in the context of becoming research writers we would want to emphasise precariousness. Being authoritative and masterful is fragile, unstable and ephemeral. It is provisional. From this perspective, the question of how to diminish or ameliorate the anxiety of doctoral research writers becomes a matter of finding ways to work productively with this condition, to embrace provisionality, rather than struggle for an unachievable sense of control. Kamler and Thomson (2006) argue that the thesis genre and scholarly writing more broadly require a balance between Barthes' writerly and readerly approaches. They call for a combination of approaches, encompassing a 'structural readerly-ness,' to ensure clarity of argument, for example, in concert with enough writerly-ness to ensure a 'good read.' This would mean ensuring sufficient invitations exist for the reader to 
play with meanings, imagine alternatives and actively engage in interpretation. In the context of the doctorate, we agree that this seems like a sensible approach.

What we would also want to emphasise, however, is that institutional and supervisory approaches to, and discourses around, research writing need to be consistent with this approach. In particular, doctoral candidates need to be supported to engage productively with the risk involved in writerly approaches to research writing. Mythologies around the doctoral thesis situate it as monolithic and impenetrable, the quintessential readerly text. A writerly doctoral thesis, on the other hand, while not in ruins - to continue the architectural metaphor - must be nonetheless more modest; what might be called precarious rather than robust writing. As Barthes says: 'the pleasure of the text is not necessarily of a triumphant, heroic, muscular type. No need to throw out one's chest' $(1976,18)$. The challenge is not to confuse precarious with poor; in other words, to encourage textual openness without inadvertently creating confusion, or lack of clarity, for example. Guidance from research advisors is critically important here. Again, Barthes offers a way forward by alluding to the role of the oblique in writerly texts:

To be with the one I love and think of something else: this is how I have my best ideas, how I best invent what is necessary to my work. Likewise for the text: it produces, in me, the best pleasure if it manages to make itself heard indirectly; if, reading it, I am led to look up often, to listen to something else. I am not necessarily captivated by the text of pleasure; it can be an act that is slight, complex, tenuous, almost scatterbrained... $(1976,24)$ 
Barthes' point here is that textual porosity, rather than robustness, can be what makes for the most engaging and thought provoking reading. There is no doubt that such ideas can seem incongruous in the context of doctoral writing. Adjectives such as 'slight', 'tenuous' and certainly 'scatterbrained', are not usually associated with good doctoral writing - even 'complex' tends to be discouraged in the interests of timely completions. We argue, however, that genuine engagement with the reader makes it necessary to question both the rhetoric around doctoral theses and overly risk adverse approaches to doctoral writing.

\section{Conclusion}

In this article we have sought to rethink authoritative writing by promoting textual porosity over robustness in the context of doctoral writing. While such thinking is certainly a long way from narrow skills based approaches to doctoral writing particularly of the 'tips and tricks' variety that Kamler and Thomson (2006) lament we also acknowledge that such writing is not without challenges. The temptation, particularly on the part of advisors, to fix rather than open up meaning in thesis texts is understandable. Treating the reader as consumer by writing as if to simply convey meaning is to some extent necessary given the genre of the doctoral thesis and its purpose. But striving simply to convey meaning is to sell the thesis short. The thesis can be richer than this; and this entails thinking differently about both writing and reading. Writing for a reader as co-writer, as suggested by Barthes and others explored in this article, re-positions both thesis author and readers, including examiners. Most significantly, by recruiting readers into a process of co-production, the thesis becomes an opportunity for the candidate not only to share their discovery but also to let readers 
share in discovery. This has a number of potential benefits. It can lead to more engaging theses, and therefore a 'better read' for examiners and others. It also shifts the notion of authoritative writing from that of being in control to being in dialogue. This re-positions the thesis writer from candidate to peer - a key objective of most doctoral programs. Such outcomes, however, require a more nuanced conceptual tool kit around research writing skills, their development, and risk. Recognising the ontological and identity issues involved in becoming research writers and, indeed, being research writers, makes such a practice unavoidably fraught and fragile. As Heidegger reminds us, this is as it should be: letting go of the quest for mastery over the world in turn opens us up to the world - it just may not be the world we had intended.

\section{References}

Aitchison, Claire, Barbara Kamler and Alison Lee. 2010. Publishing pedagogies for the doctorate and beyond. Oxon, UK: Routledge.

Barnacle, R. 2005. Research education ontologies: exploring doctoral becoming, Higher Education Research and Development 24, 2: 179-188.

Barnacle, R. and G. Dall'Alba. 2011. Research degrees as professional education? Studies in Higher Education 36, no.4: 459-570.

Barnett, R. 2005. Recapturing the universal in the university. Educational Philosophy and Theory 37, no.6: 785-797.

Barthes, Roland. 1976. The pleasure of the text. Trans. R. Miller. London: Jonathan Cape.

Barthes, Roland. 1970. S/Z. Trans. R. Miller. London: Cape.

Blake, Nigel, Paul Smeyers, Richard Smith, and Paul Standish. 2000. Education in an age of nihilism. London: Routledge Falmer.

Bourner, T., R. Bowden and S. Laing. 2001. Professional doctorates in England. Studies in Higher Education 26, no.1: 65-83.

Cross, N. 1999. Natural intelligence in design. Design Studies 20, no.1:25-39.

Dall'Alba, Gloria. 2009. Learning to be professionals. Dordrecht: Springer.

Dall'Alba, G. 2005. Improving teaching: Enhancing ways of being university teachers. Higher Education Research and Development 24, no.4: 361-372.

Dall'Alba, G. and R. Barnacle. 2007. An ontological turn for higher education. Studies in Higher Education 32, no.6: 679-691.

Heidegger, Martin. 2001/1951. Language. In Poetry, language, thought. Trans. Albert Hofstadter. New York: Harper and Row.

Heidegger, Martin. 1977/1954. The question concerning technology. In The question concerning technology and other essays (pp. 3-35). Trans. W. Lovitt. New York: Harper and Row. 
Heidegger, Martin. 1971. The nature of language. In On the way to language. Trans. Peter D. Hertz. New York: Harper \& Row.

Kamler, Barbara and Pat Thomson. 2006. Helping Doctoral students write: Pedagogies for supervision. Abingdon, UK: Routledge.

Lovitt, W. (1977). Introduction. In M. Heidegger, The question concerning technology and other essays. Trans. W. Lovitt. New York: Harper and Row.

Merleau-Ponty, Maurice. 1962/1945. Phenomenology of perception. London: Routledge \& Kegan Paul.

Milne, A. A. 2007/1928. The house at Pooh corner. London: Egmont UK Limited.

van Schaik, Leon. 2005. Mastering architecture: becoming a creative innovator in practice. London: Wiley-Academy.

Sandberg, J., \& Alvesson, M. 2011. Ways of constructing research questions: Gapspotting or problematization? Organization 18, no.1: 23-44.

Schön, Donald A. 1987. Educating the reflective practitioner: Toward a new design for teaching and learning in the professions. San Francisco: Jossey-Bass.

van Manen, Max and C. Adams. 2009. The phenomenology of space in writing online. In ed. G. Dall'Alba, Exploring education through phenomenology: Diverse approaches (pp. 4-15). Oxford: Wiley-Blackwell.

van Manen, Max. 2002a. Writing in the dark. In ed. M. van Manen, Writing in the dark: Phenomenological studies in interpretive inquiry (pp. 237-252). London, Ontario: Althouse Press.

van Manen, Max. 2002b. Writing phenomenology. In ed. M. van Manen, Writing in the dark: Phenomenological studies in interpretive inquiry (pp. 1-8). London, Ontario: Althouse Press.

Word count: 6,002 